\title{
Investment activity at the objects of specially protected natural territories of the Tyumen region
}

\author{
Olga Bogdanova ${ }^{1, *}$ \\ ${ }^{1}$ Tyumen industrial University, 625000, Volodarsky Street, 38, Tyumen, Russian Federation
}

\begin{abstract}
This article discusses the possibilities of investment activities on the territories of objects of specially protected natural territories. The analysis of existing objects with identification of possible types of business activity within the current legislation is carried out. The purpose of this study was to determine the main directions of development of investment activity in territories of especially protected natural objects, and to offer basic stages of the evaluation presents the calculation of key performance criteria as a result of implementation of investment projects of ecological tourism. Criteria for ecological tourism are considered and an algorithm for implementing an investment project on the territory of an object, a specially protected natural area, is developed on the example of the Tyumen region. When writing the article, we used the General scientific method (analysis, synthesis, logical method), statistical method, sample observation method, and system analysis. The main results of this study can be considered the development of an algorithm for evaluating investment projects in specially protected natural areas, as well as methods for their evaluation.
\end{abstract}

\section{Introduction}

According to modern concepts, the objects of specially protected natural territories, in addition to nature conservation, should contribute to hanging the welfare of the local population, provide environmental education and provide opportunities for the development of tourism and recreation in the natural environment. Currently, Russia implements programs for the arrangement of specially protected natural areas for the period up to 2020 in order to develop ecological tourism. It has been established that one of the main problems in the development of specially protected natural areas is the lack of a modern tourist and recreational infrastructure that allows ecological tourism without prejudice to the conservation of natural complexes. To date, the territories of protected areas are withdrawn from circulation and cannot participate in investment activities., Figure 1 shows a map of investment proposals in the Tyumen region, among them there is not one located on the territory of protected areas [1].

\footnotetext{
*Corresponding author: chernyheg@tyuiu.ru
} 


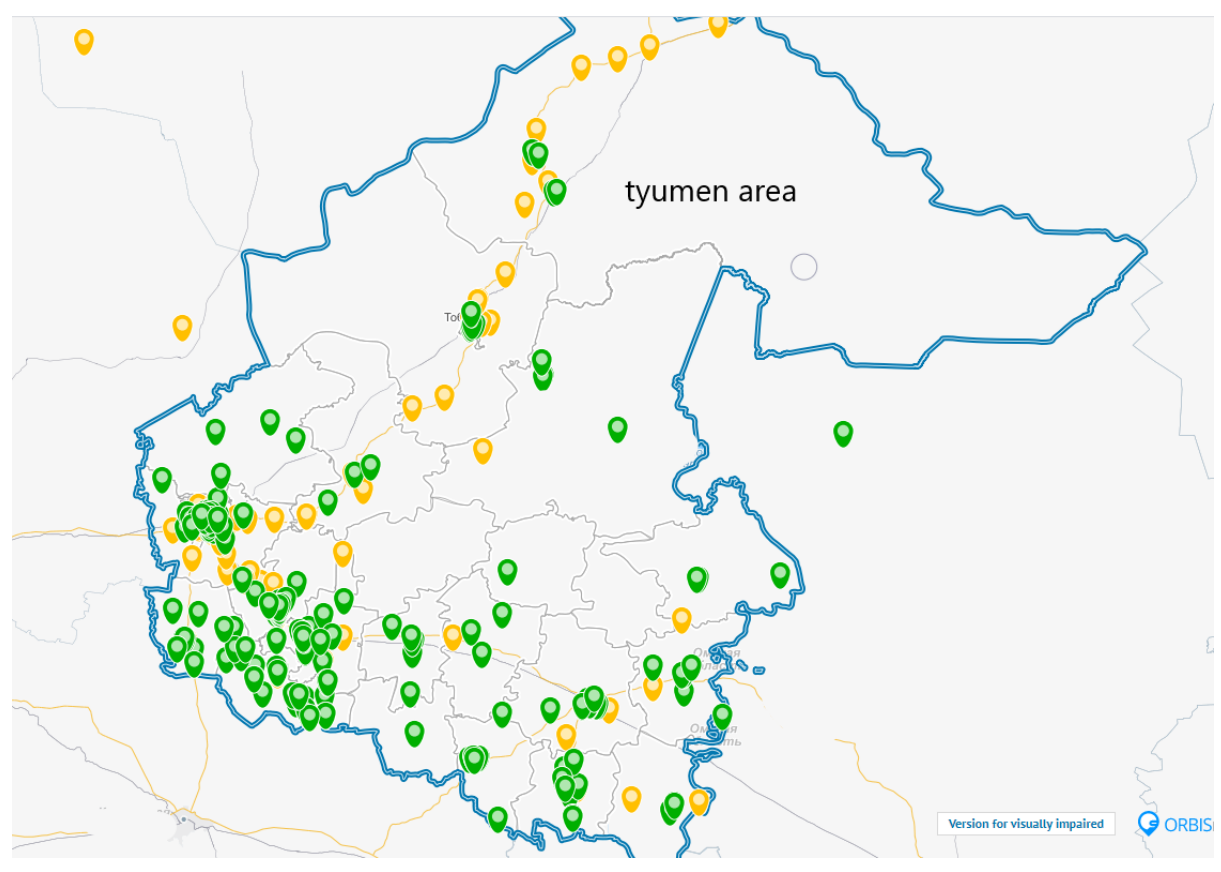

Fig. 1. A fragment of a map of objects of investment activity in the Tyumen region.

\section{Analysis}

A comprehensive analysis of the competitive positions of the Tyumen region, its advantages in terms of the possibility of their implementation in the long term and ensuring on this basis sustainable economic growth, involves taking into account the totality of both internal and external factors and conditions of territorial development. In the field of ecology and environmental management of the Tyumen region in the long term, the main priority should be to improve the quality of the natural environment and the environmental conditions of human life, the formation of a balanced environmentally-friendly model for the development of the economy and environmentally competitive industries.

In our opinion, the prerequisites for the emergence of investment activity in relation to the objects of protected areas are the mutual interests of the participants in the implementation of the product of the territory and the possibility of using the resources of protected areas for innovative development.

An important factor is the demand for products and services of protected areas (potentially high, because the person and quality of life a priori depends on the application of the principles of sustainable development in the production of any product or service), which is currently not satisfied due to limited supply. The basis of innovative processes is the need to adapt the activities of protected areas to the changing economic conditions and the configuration of the markets of suppliers and consumers [2].

Thus, we have analyzed the main potential commercial (entrepreneurial) services provided at the facilities of specially protected natural territories of the Tyumen region (Table 1). 
Table 1. Potentially possible commercial (entrepreneurial) services in the territory of protected areas.

\begin{tabular}{|c|c|c|}
\hline Opportunity & Explanation & $\begin{array}{c}\text { Name of the object of } \\
\text { protected areas }\end{array}$ \\
\hline $\begin{array}{l}\text { Recreational tours surrounded } \\
\text { by nature with emotional and } \\
\text { aesthetic goals }\end{array}$ & $\begin{array}{l}\text { Walking tours on specially } \\
\text { designated ecological trails, } \\
\text { conducted independently or } \\
\text { with a guide }\end{array}$ & $\begin{array}{c}\text { Abalaksky } \\
\text { natural-historical } \\
\text { complex }\end{array}$ \\
\hline Therapeutic tours & $\begin{array}{l}\text { Objects of specially protected } \\
\text { natural territories with a wide } \\
\text { range of medical factors: } \\
\text { treatment using mineral water, } \\
\text { mud, etc. }\end{array}$ & $\begin{array}{l}\text { Zoological reserve of } \\
\text { Vikulovskaya }\end{array}$ \\
\hline Sports and adventure tours & $\begin{array}{l}\text { River rafting, horseback riding, } \\
\text { deer rides, orienteering, rock } \\
\text { climbing, hiking }\end{array}$ & $\begin{array}{l}\text { monument of regional } \\
\text { significance Lebyazhye }\end{array}$ \\
\hline Ethnographic Tours & $\begin{array}{l}\text { Excursions to the settlements } \\
\text { of small peoples of the North } \\
\text { (Khanty and Mansi) }\end{array}$ & Numto national Park \\
\hline Archaeological tours & $\begin{array}{l}\text { Monuments of the Iron and } \\
\text { Bronze Ages, the temple }\end{array}$ & $\begin{array}{c}\text { the monument's natural values } \\
\text { andreevskie lakes }\end{array}$ \\
\hline Cultural Tours & $\begin{array}{l}\text { Sights of settlements in } \\
\text { protected areas, architectural } \\
\text { monuments, museums }\end{array}$ & $\begin{array}{c}\text { places of residence of } \\
\text { indigenous and minority } \\
\text { peoples }\end{array}$ \\
\hline Cognitive tourism & $\begin{array}{l}\text { Excursions and tourist routes } \\
\text { that expand knowledge about } \\
\text { the processes and phenomena } \\
\text { of nature (Northern Lights) }\end{array}$ & Malaya Sosva nature reserve \\
\hline Hunting & $\begin{array}{l}\text { Creation of hunting grounds } \\
\text { for sports hunting }\end{array}$ & Tyumen nature reserve \\
\hline Fishing & $\begin{array}{l}\text { Formation of fishing sites for } \\
\text { the organization of sport } \\
\text { fishing }\end{array}$ & Tobolsk reserve \\
\hline Wild gathering & $\begin{array}{l}\text { Organization of campsites for } \\
\text { those who want to pick berries, } \\
\text { mushrooms, nuts for personal } \\
\text { use (not for sale) }\end{array}$ & nizhnetavdinsky reserve \\
\hline
\end{tabular}

Thus, in our opinion, the development of long-term, specialized (more expensive) tours for a small number of groups instead of mass tourism is more acceptable on the territory of protected areas. Also, part of the tourist routes may lie in a special zone of the protected areas without violating its conservation. Protected areas can also act as organizers of environmental programs in the field, provide visitors with guides, guides and scientific consultants from among their employees and local residents, organizing excursion provision, transport services, sale of souvenirs, etc.

The resources of fishing and hunting of the Tyumen region are presented in Figure 2, 3. 


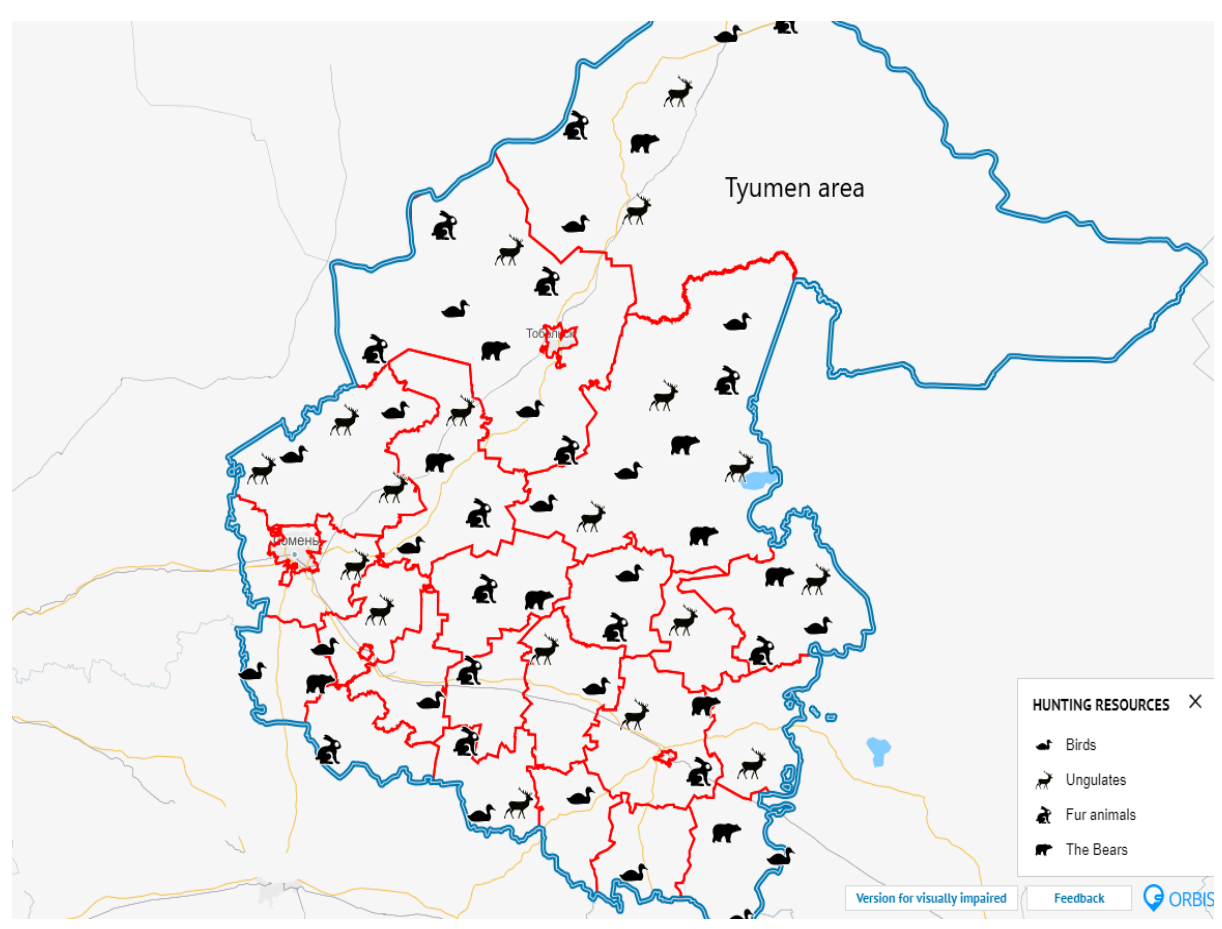

Fig. 2. Fragment of a map of the resources of hunting of the Tyumen region.

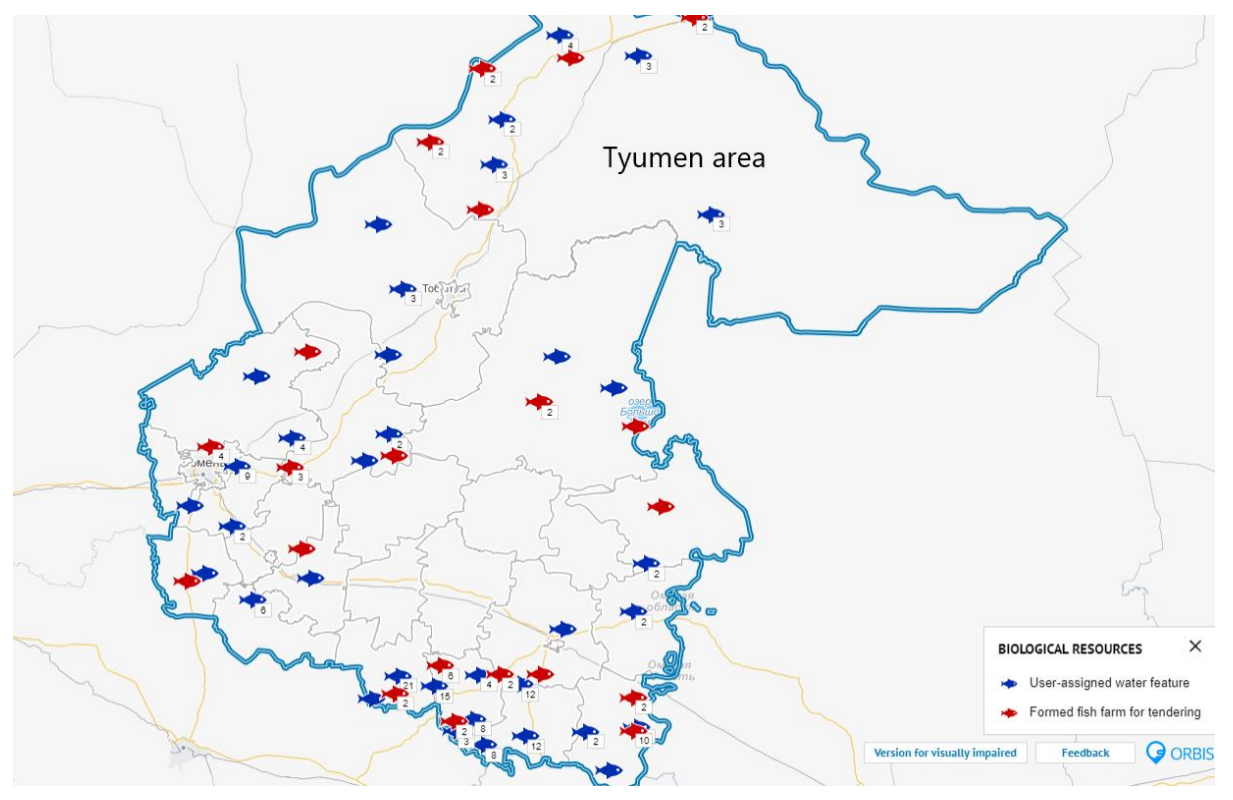

Fig. 3. Fragment of a map of the resources of fishing of the Tyumen region.

\section{Calculation}

The methodology for evaluating investment projects in protected areas was described in detail in the work of LI Starkova, investment projects were examined from the perspective 
of environmental and economic justification. The contradictory goals of socio-economic development and the preservation of the environment, natural and cultural values make us critically rethink the methods of environmental and economic substantiation of such investment projects. In other words, when justifying such projects, it is necessary to take into account not only socio-economic, but also environmental factors and risks that should receive an economic assessment. The tasks of assessing the environmental and economic efficiency of infrastructure investment projects in the work considered [3,4].:

a) obtaining quantitative and qualitative criteria for making decisions on the admissibility or inadmissibility of the project;

b) ensuring the selection of a project option with the lowest environmental and social costs.

The following criteria are proposed to be used as criteria for environmental project management:

1) the environmentally adjusted economic effect of the project, estimated using the NPVE indicator which takes into account the environmental costs of environmental measures,

2) non-financial indicator of digression as a result - D.

Thus, the environmentally adjusted economic effect of the project, estimated using the NPVe indicator, is calculated as follows:

$$
\ni=\sum \frac{\pi_{t}-z_{t}}{(1+r) t}
$$

where: $\mathrm{T}$ - the total duration of the project life cycle, years; rit - cash receipts in year $\mathrm{t}$, million rubles; $\mathrm{Z}$, - cash payments (costs) and environmental costs in year $\mathrm{t}$, million rubles; $t$ is the number of the year from the start of the project; $g$ is the discount rate, $\%$. From the point of view of the methodology for the analysis of investment projects, this is an environmentally adjusted net present value (NPV Net Present Value) from the implementation of the project.

In our opinion, it is necessary to evaluate investment projects of specially protected natural territories from the position of environmental and economic analysis and use the environmentally adjusted economic effect of the project as the main quantitative indicator, while developing three scenarios:

- construction of facilities for the reception of tourists;

- limited construction;

- refusal to build facilities on the territory of the national park in order to preserve the natural pristine spit.

To date, the procedure for selecting investment projects is referred by the legislators to the competence of state authorities of the constituent entities of the Russian Federation, based on the application of such criteria for evaluating investment projects as [2]:

-economic efficiency;

budgetary efficiency;

-social significance of the project for the territory of the municipality;

environmental safety of production;

-quality and cost of products relative to similar goods sold on the Russian market;

- payback period of the investment project;

- the average salary of employees;

- the amount of the applicant's own funds and the volume of foreign investment, etc.

To obtain a certain level of development of effective land resources management in protected areas of the Tyumen region, the author has improved the methodological sequence of actions for the formation of an investment project, taking into account the 
possibilities of using various scenarios for the implementation of investment projects on the territory of specially protected natural territories.

The difficulty of investing in the territory of specially protected natural sites lies in the non-commercial nature of this type of territory, in the absence of a formed market and prices for recreational services.

Analysis of publications on the economics of specially protected natural areas shows that in order to attract investment, the organizers of ecotourism and other activities on the territory of protected areas need to select profitable innovative projects that generate income that exceeds costs. Criteria expressing a different degree of economic feasibility of investment projects of protected areas can be the amount of net income, the ratio of income-expenses, internal rate of return.( Table 2.)

Table 2. Calculation of criteria for the Tyumen reserve.

\begin{tabular}{|c|c|c|c|}
\hline \multirow{2}{*}{ Criteria } & \multicolumn{3}{|c|}{ A variant of organizing the territory of the Tyumen State Nature Reserve } \\
\cline { 2 - 4 } & $\begin{array}{c}\text { Organization of } \\
\text { recreation for the } \\
\text { population }\end{array}$ & $\begin{array}{c}\text { Amateur hunting and } \\
\text { fishing }\end{array}$ & $\begin{array}{c}\text { Ecotourism with } \\
\text { elements of } \\
\text { hunting and } \\
\text { fishing }\end{array}$ \\
\hline Net income, RUB / ha & 30195 & 65269 & 42157 \\
\hline $\begin{array}{c}\text { The ratio of income- } \\
\text { expenses, } \%\end{array}$ & 3.05 & 3.02 & 2.37 \\
\hline $\begin{array}{c}\text { Internal rate of } \\
\text { return,\% }\end{array}$ & 5.01 & 5.29 & 8.78 \\
\hline
\end{tabular}

Thus, it becomes obvious that the development of investment activities in specially protected areas will improve the quality of life of the local population, increase allocations to local budgets, create additional jobs, etc.

\section{Sentence}

Also, in our opinion, it becomes important to consider the criteria for ecotourism, because we are talking about territories with a special regime of use, within which economic activity is generally prohibited, a solution to this issue is possible provided that any objects are located in the territorial zones of protected areas, where this type of activity is allowed statutory documents [5].
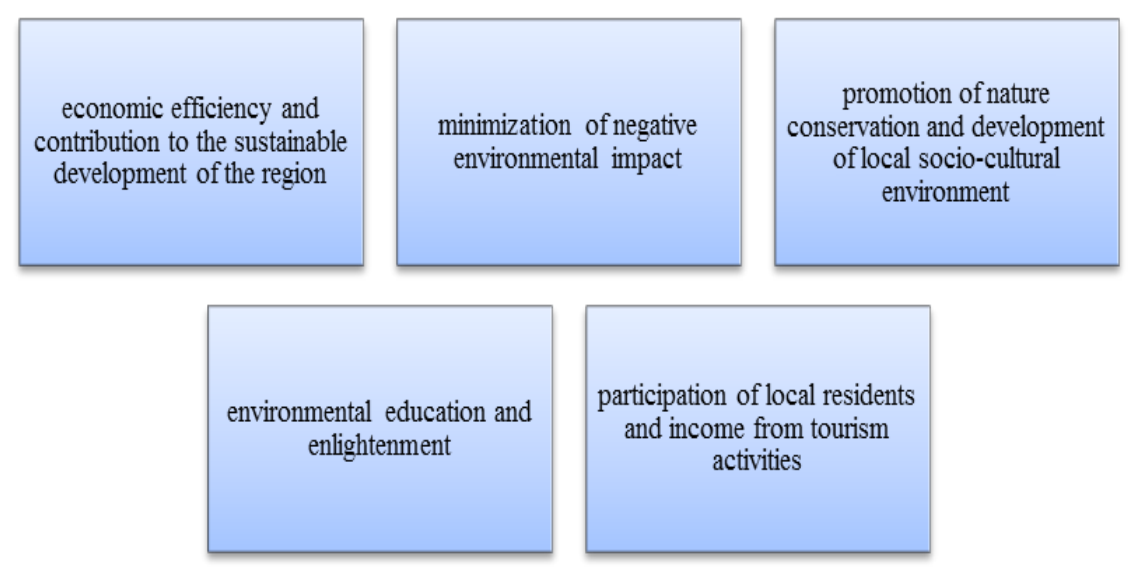

Fig. 4. System of environmental criteria. 
Today, in the territories of protected areas, a differentiated regime of special protection is established taking into account their natural, historical, cultural and other features. Based on these features in the territories of protected areas, various functional zones can be distinguished, including:

a) a reserve within which any economic activity and recreational use of the territory is prohibited;

b) specially protected, within which the conditions for the preservation of natural complexes and objects are provided and in the territory of which strictly regulated visits are allowed;

c) educational tourism, designed to organize environmental education and familiarization with the attractions of the national park;

d) recreational, intended for recreation;

e) the protection of historical and cultural objects, within which the conditions for their conservation are provided;

f) visitor services intended for accommodation of overnight places, campsites and other objects of tourist service, cultural, domestic and information services for visitors;

g) for economic purposes, within the framework of which, the economic activity necessary to ensure the functioning of the national park is carried out.

In our work, which is mainly based on the study of regional objects of specially protected natural territories, a great interest in a group of investment projects in the field of regional protected areas objects that ensure the development of infrastructure, roads, and jobs for the local population is appropriate.

The tendency to involve objects of specially protected natural territories in the economic turnover requires a clear idea of their economic significance; this is necessary both for the supporters of the transformation of protected areas into the form of real estate objects, and for the defenders of the traditional idea of nature protection, as a free environment of public property, and the healing of our people.

Consider the algorithm for implementing an investment project on the territory of specially stored objects (Fig. 5.). 


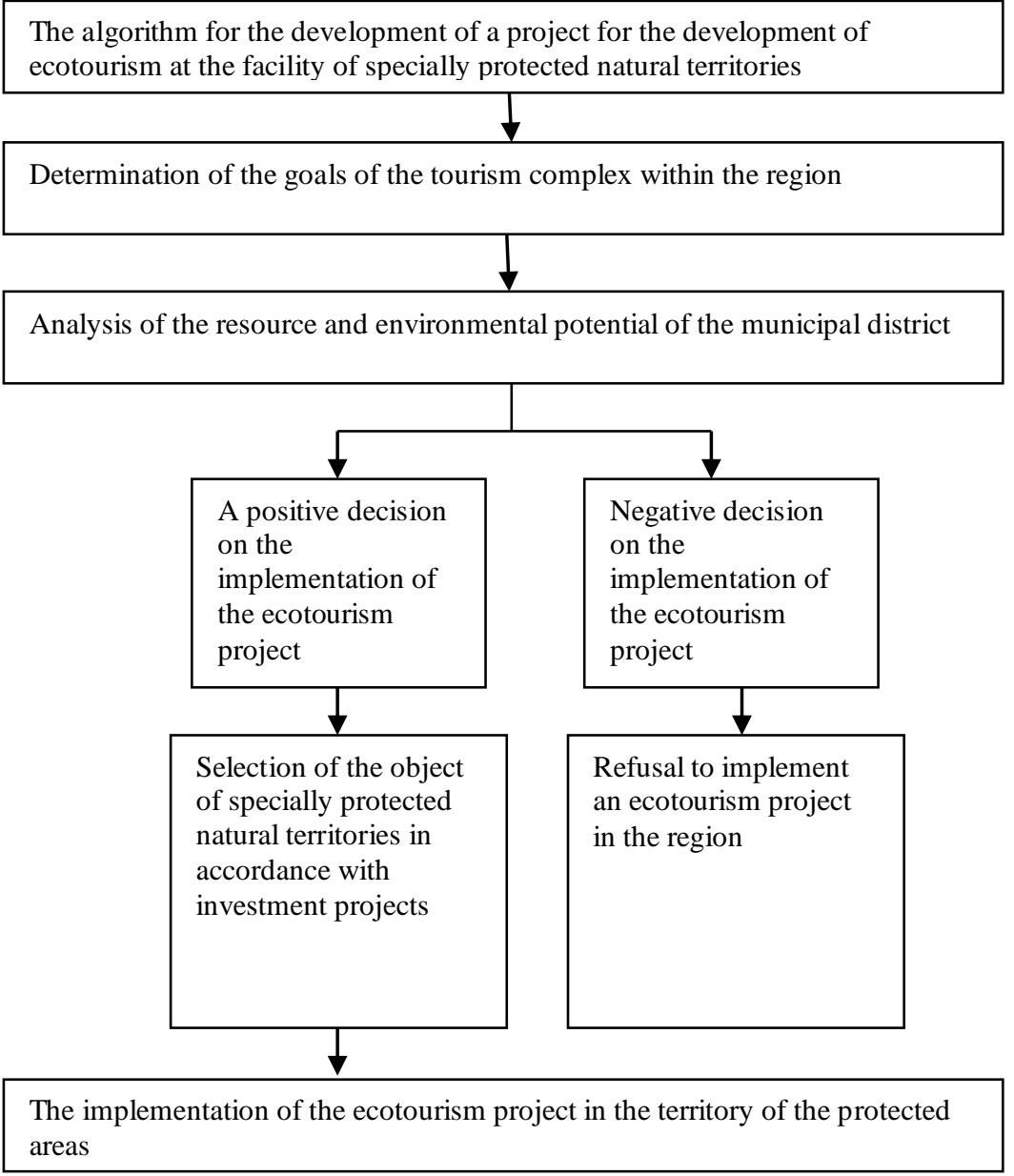

Fig. 5. Algorithm for the implementation of an investment project on the territory of specially stored objects.

The difficulty of investing in the territory of specially protected natural sites lies in the non-commercial nature of this type of territory, in the absence of a formed market and prices for recreational services.

Analysis of publications on the economics of specially protected natural areas shows that in order to attract investment, the organizers of ecotourism and other activities on the territory of protected areas need to select profitable innovative projects that generate income that exceeds costs. But at the same time, it should be noted that investment management in the territories of protected areas, first of all, should be aimed at protecting the environment, creating an economic mechanism identical to that used in managing the regional economies by ensuring uniform approaches to organizing production planning and environmental protection, promoting greening production and reduction of anthropogenic impact on recreational resources.

This approach should ensure the development of tourism along a trajectory that helps to:

a) natural complexes were not affected;

b) mechanisms have been created to increase the employment of local residents; 
c) there was an opportunity for revenue growth, both environmental protection structures and local settlements;

d) environmental education developed.

The idea of implementing investment activities in the form of ecological tourism in the protected areas is based on long-term goals - this is the transformation of the region that has the greatest natural resource potential for the development of ecotourism into a dynamically developing one, which ensures, on the basis of the reasonable consumption of recreational, especially valuable resources of specially protected natural areas. High rates of economic growth should become a means of achieving significant environmental benchmarks, successfully solving the urgent problems of structural and technological modernization of the recreational economy, and realizing additional competitive advantages of resort and tourist regions in the international arena.

\section{References}

1. O. Mezenina, A protection Place: GOS. University of land management, 383 (2005)

2. L.B. Baysultanova, Scientific-analytical journal: Economic and Legal Bulletin, GOU VPO "Russian Law Academy of the Ministry of Justice of the Russian Federation, Makhachkala (2009)

3. L.I. Starkova, Environmental Economics, No. 6, 50-66 (2011)

4. S. Sternad, K. Sharma, S. Bobek, American Journal of Economics and Control Systems Management, No. 2, 24-30 (2014)

5. E. Trutnev, L. Bandorin, T. Gudz, M. Safarova, M. Yakubov, Urban regulation: Fundamentals of regulation of urban development in the context of the real estate market, 13-16 (2008)

6. Beregovskih, Urban planning documentation, 1, 18-19 (2008)

7. G. de Roo, D. Miller, Urban Environmental Planning. Policies, Instruments and Methods in an International Perspective, 128-136 (2016)

8. Institute of territorial planning "Grad», The decision of the conference "Urban planning and management, environmental quality and the business climate", 2-3 (2013)

9. G. Potaev, Trends of urban development, 11-19 (2014)

10. J. Carter, S. Jay, M. Shorts, C. Wood, Strategic Environmental Assessment and Land Use Planning an International Evaluation, 6-12 (2006)

11. N. Reimers, F. Stilmark, Specially protected natural territories (Thought, 296, 1978)

12. International classification of specially protected natural territories. Electronic resource URL: https: //pandia.ru

13. Federal Law of 14.03. 1995 No. 33 "On Specially Protected Natural Territories"

14. Steck B, Sustainable Tourism as a Development Option. Practical Guide for Local Planners (Developers and Decision Makers, 2000)

15. Kustysheva, IOP Conference Series: Materials Science and Engineering, 262 (1), № 012166 (2017) DOI: 10.1088/1757-899X/262/1/012166 